\title{
Binding of Placental Lactogen and Growth Hormone to Fetal Sheep Fibroblasts
}

\author{
JOHN FOWLKES AND MICHAEL FREEMARK
}

Departments of Pediatrics and Cell Biology, Duke University Medical Center, Durham, North Carolina 27710

\begin{abstract}
Growth hormone $(\mathrm{GH})$ regulates growth and development in the postnatal period but lacks somatotropic activity in the fetus. In contrast, the placental hormone placental lactogen (PL) stimulates amino acid transport, DNA synthesis, and somatomedin production in isolated fetal tissues, suggesting that PL may function as a "fetal GH." To elucidate the mechanisms by which PL exerts GH-like effects in fetal tissues, we examined the binding of PL, GH, and prolactin to cultured skin fibroblasts obtained from midgestational fetal lambs. Ovine fetal fibroblasts bound radiolabeled ovine PL (oPL) specifically and with high affinity $\left(\mathrm{EC}_{50} 0.20 \mathrm{nM}\right)$. In competitive displacement assays using ${ }^{125} \mathrm{I}-\mathrm{OPL}$ as the radioligand, the potency of unlabeled oPL was eight to 12 times greater than that of ovine $\mathbf{G H}$ and $\simeq \mathbf{1 0 0 0}$ times greater than that of ovine prolactin. Covalent cross-linking of ${ }^{125} \mathrm{I}-\mathrm{oPL}(22$ kD) to ovine fetal fibroblasts revealed a specific hormonereceptor complex with an apparent $M_{r}$ of 130000 , suggesting that the high affinity oPL binding site has a molecular mass of approximately $108 \mathrm{kD}$. The specific bindings of radiolabeled ovine $\mathrm{GH}(0.6 \%$ per $250 \mu \mathrm{g}$ protein) and ovine prolactin $(0.04 \%$ per $250 \mu$ g protein) were only $1 / 15$ and $1 / 230$ that of radiolabeled oPL $(9.1 \%$ per $250 \mu \mathrm{g}$ protein), and no specific cross-linking of ${ }^{125}$ I-ovine GH or ${ }^{125}$ I-ovine prolactin to ovine fetal fibroblasts was detected. These findings demonstrate preferential binding of PL by isolated fetal sheep fibroblasts in culture, providing a cellular mechanism whereby PL may exert growth-promoting effects in the fetus. (Pediatr Res 32: 200-203, 1992)
\end{abstract}

\section{Abbreviations}

GH, growth hormone

PL, placental lactogen

PRL, prolactin

oPL, ovine placental lactogen

oGH, ovine growth hormone

oPRL, ovine prolactin

$\mathrm{BS}^{3}$, Bis(sulfosuccinimidyl)suberate

$\mathrm{EC}_{50}, \mathbf{5 0 \%}$ effective concentration

The human fetus at midgestation grows at a rate 12 times greater than that of the child in midpuberty (1); however, the regulation of fetal growth by fetal and placental hormones is poorly understood (2). Although GH plays a major role in the control of postnatal growth, it appears to play little or no role in the control of growth in the fetus $(2,3)$. Several lines of evidence

Received December 27, 1991; accepted March 31, 1992.

Correspondence: John L. Fowlkes, M.D., Box 3080, Bell Building, Duke UniCorrespondence: John L. Fowlkes, M.D., Bor
versity Medical Center, Durham, NC 27710.

Supported by Diabetes Research \& Education Foundation (J.F.) and NIH Grants HD24192 and HD00901, MOD no. 1-1104, and a Genentech teaching grant (M.F.). suggest that PL, a 22-kD polypeptide hormone produced by the fetal placenta, plays a role in the control of fetal growth. PL circulates in fetal plasma from midgestation to parturition in humans, sheep, cows, and mice (for review see Ref. 4) and binds with high affinity to microsomal fractions of ovine (5-9) and human fetal liver (10), bovine endometrium $(11,12)$, and human fetal skeletal muscle (10). PL exerts metabolic effects on glycogen metabolism in isolated fetal sheep and rat hepatocytes $(6,13-$ $15)$ and stimulates amino acid uptake, $\left[{ }^{3} \mathrm{H}\right]$ thymidine incorporation, and IGF production in human fetal fibroblasts, myoblasts, and pancreatic islet cells (16-18). In the mid- and lategestation human fetus, plasma PL concentrations correlate positively with fetal plasma IGF-I concentrations and independently with birth weight (19).

The mechanisms by which PL exerts growth-promoting effects in fetal tissues are unknown. To clarify events critical for PL activity at the cellular level, we characterized the binding of oPL to isolated skin fibroblasts from fetal lambs at midgestation. We then compared the binding of oPL to fetal sheep fibroblasts with that of oGH and oPRL.

\section{MATERIALS AND METHODS}

Hormones. Binding studies were performed using purified oPL (20) or recombinant oPL (21), the latter a gift from Genentech Inc. (South San Francisco, CA). There were no differences in the binding of the two oPL preparations to fetal sheep fibroblasts or to sheep liver microsomes. oGH (NIH-GH-15) and oPRL (NIHP-S14) were obtained from the National Hormone and Pituitary Program, National Institute of Arthritis, Digestive Disease, and Kidney. Each hormone was radiolabeled with ${ }^{125} \mathrm{Na}$-iodine to a sp act of $50-90 \mu \mathrm{Ci} / \mu \mathrm{g}$ using 1,3,4,6-tetrachloro-3,6-diphenyl glycouril (iodo-Gen; Pierce Chemical Co., Rockford, IL) as the catalyst (8). Each preparation of ${ }^{125} \mathrm{I}-\mathrm{oPL}$ and ${ }^{125} \mathrm{I}-\mathrm{oGH}$ bound specifically to maternal sheep liver membranes (at least $10 \%$ per mg protein) and pregnant rabbit liver membranes (at least $40 \%$ per mg protein) during a $2-\mathrm{h}$ incubation at $22^{\circ} \mathrm{C}$. The preparation of ${ }^{125} \mathrm{I}$-oPRL bound specifically $(8-10 \%$ per $\mathrm{mg}$ protein) to pregnant rat liver microsomes.

Cell culture. Fibroblast cultures were prepared from skin biopsies obtained from 81-d gestation fetal lambs. One-mm fragments were allowed to attach to $25-\mathrm{cm}^{2}$ flasks for $1 \mathrm{~h}$ and then overlaid with minimal essential media (Gibco Laboratories, Grand Island, NY) supplemented with $10 \%$ defined FCS (Hyclone Laboratories, Logan, UT), $0.1 \mu \mathrm{M}$ dexamethasone, $25 \mu \mathrm{U} / \mathrm{mL}$ penicillin $\mathrm{G}, 25 \mu \mathrm{g} / \mathrm{mL}$ streptomycin, $50 \mu \mathrm{g} / \mathrm{mL}$ gentamicin, and $1 \mu \mathrm{g} / \mathrm{mL}$ amphotericin B. Fibroblasts were plated in either 6-, 12-, or 24well culture plates (Costar, Cambridge, MA, and Falcon, Lincoln Park, NJ) and grown to confluence before use in binding or cross-linking studies. Fibroblasts were used between passages 1 and 9.

oPL binding to fetal skin fibroblasts in culture. Confluent fibroblast monolayers were washed three times with $1 \mathrm{~mL}$ of cold binding buffer ( $25 \mathrm{mM} \mathrm{N}$-2-hydroxyethylpiperazine- $N^{\prime}-2$ ethanesulfonic acid, $120 \mathrm{mM} \mathrm{NaCl}, 5 \mathrm{mM} \mathrm{KCl}, 2.5 \mathrm{mM} \mathrm{CaCl}_{2}$, 


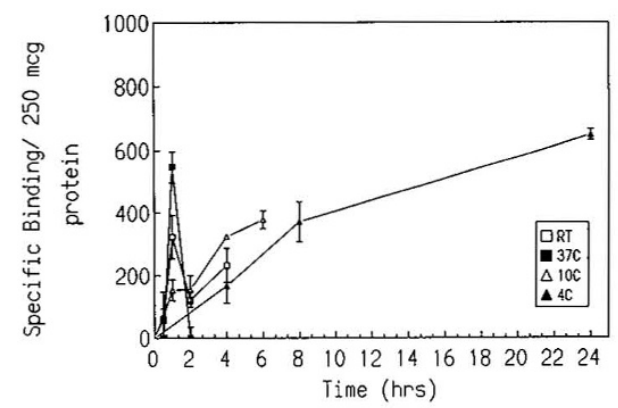

Fig. 1. Time and temperature dependence of ${ }^{125} \mathrm{I}-\mathrm{oPL}$ binding to fetal sheep fibroblasts. Radiolabeled oPL was incubated with fetal sheep fibroblasts in the presence or absence of unlabeled hGH $(10 \mu \mathrm{g} / \mathrm{mL})$ at $4^{\circ} \mathrm{C}(\Delta), 10^{\circ} \mathrm{C}(\triangle), 37^{\circ} \mathrm{C}(\mathbf{\square})$, or room temperature ( $\square$ ) for various times. Specific binding was calculated by subtracting the amount of binding that occurred in the presence of excess unlabeled hormone (nonspecific binding) from the total binding and expressed as cpm per $250 \mu \mathrm{g}$ protein. Values represent the mean \pm SEM of duplicate values.

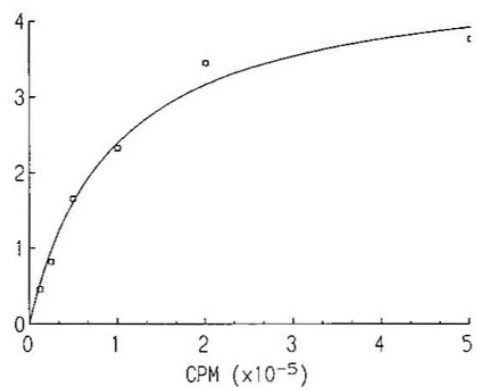

Fig. 2. Saturation of the oPL receptor in sheep fetal fibroblasts. Fetal sheep fibroblasts were incubated with various concentrations of ${ }^{125} \mathrm{I}$-oPL in the absence or presence of unlabeled hGH $(10 \mu \mathrm{g} / \mathrm{mL})$ at $4^{\circ} \mathrm{C}$ for 20 to $24 \mathrm{~h}$. Specific binding was calculated by subtracting the amount of binding that occurred in the presence of excess unlabeled hormone from the total binding. Values represent the mean of duplicate values.

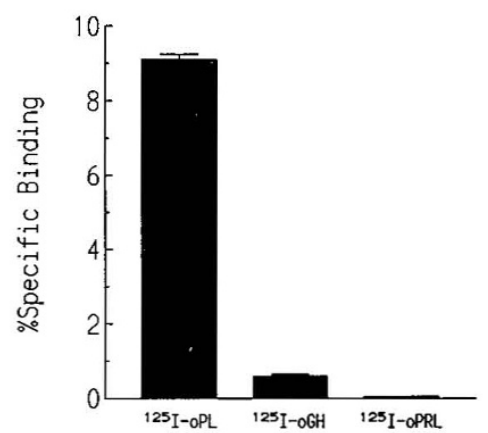

Fig. 3. Comparative binding of ${ }^{125} \mathrm{I}-\mathrm{oPL},{ }^{125} \mathrm{I}-\mathrm{oGH}$, and ${ }^{125} \mathrm{I}-\mathrm{oPRL}$ to fetal sheep fibroblasts. Radiolabeled oPL, oGH, or oPRL $(\simeq 100000$ $\mathrm{cpm} /$ well) were incubated with fetal sheep fibroblasts in the absence or presence of excess unlabeled hormone for 20 to $24 \mathrm{~h}$ at $4^{\circ} \mathrm{C}$. Percentage of specific binding was calculated by subtracting the amount of binding that occurred in the presence of excess unlabeled hormone from the total binding and expressed as a percentage of the total radioactivity added per $250 \mu \mathrm{g}$ protein. Values represent the mean of triplicate values \pm SEM. Similar results were obtained in three separate experiments.

$2.5 \mathrm{mM} \mathrm{MgCl}_{2}, 11 \mathrm{mM}$ glucose, $0.1 \%$ BSA, pH 7.5). Cells were incubated with either radiolabeled oPL, recombinant oPL, oGH, or oPRL (each $\simeq 100000 \mathrm{cpm}, \simeq 0.1 \mathrm{nM}$ ) in the presence or absence of unlabeled hormones for various times and temperatures to determine receptor saturability, affinity, and time and temperature dependence. Binding was terminated by washing the cells three times with cold binding buffer; the cells were then

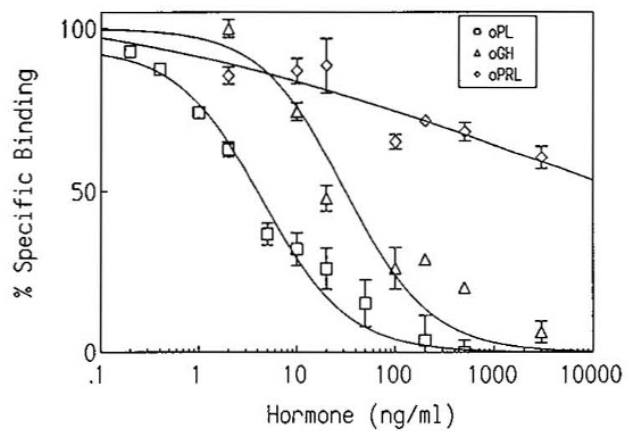

Fig. 4. Effects of unlabeled oPL, oGH, and oPRL on the binding of ${ }^{125} \mathrm{I}$-oPL to fetal sheep fibroblasts. Radiolabeled oPL $(\simeq 100000 \mathrm{cpm} /$ well) was incubated with fetal sheep fibroblasts in the absence or presence of increasing concentrations of either oPL, oGH, or oPRL at $4^{\circ} \mathrm{C}$ for 20 to $24 \mathrm{~h}$. Percentage of specific binding was calculated by subtracting the amount of binding that occurred in the presence of unlabeled hormone from the total binding and expressed as a percentage of the total radioactivity added. Values represent the mean \pm SEM of triplicate values. Curve fitting was generated by a one-site competitive binding curve equation using INPLOT software. Similar or identical results were noted in five separate experiments.

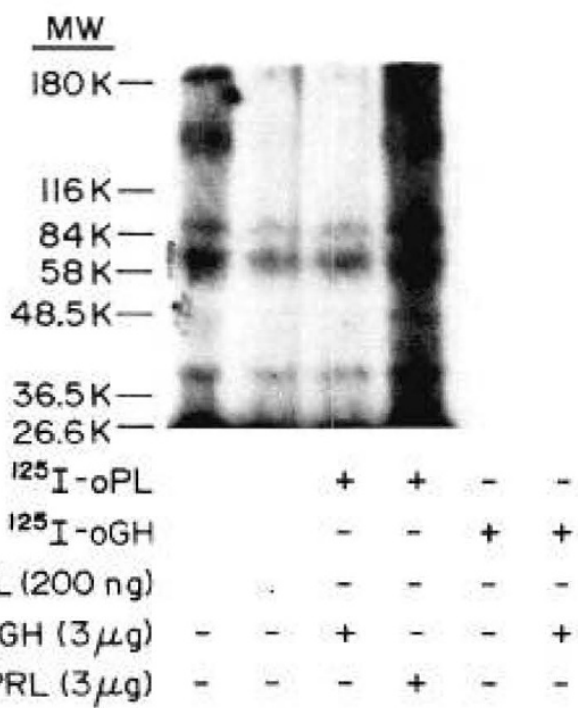

Fig. 5. Cross-linking of ${ }^{125} \mathrm{I}-\mathrm{oPL}$ and ${ }^{125} \mathrm{I}-\mathrm{oGH}$ to fetal sheep fibroblasts. Fetal sheep fibroblasts were incubated with ${ }^{125} \mathrm{I}$-oPL or ${ }^{125} \mathrm{I}-\mathrm{oGH}$ $\left(\simeq 1 \times 10^{6} \mathrm{cpm} / \mathrm{mL}\right)$ in the presence $(+)$ or absence $(-)$ of oPI, oGH, or oPRL at $4^{\circ} \mathrm{C}$ for 20 to $24 \mathrm{~h}$. Cross-linking was performed using $0.5 \mathrm{mM}$ DSS as described in Materials and Methods. Solubilized cell extracts were analyzed on a $7.5 \%$ SDS-polyacrylamide gel under reducing conditions. Free radioactivity at the bottom of the gel was cut off. Similar or identical results were noted in at least four separate experiments.

solubilized in $1 \mathrm{~N} \mathrm{NaOH}$. Radioactivity in the cell-solubilized fractions was determined by gamma scintillation spectrometry.

Cross-linking of ${ }^{125} \mathrm{I}-\mathrm{oPL}$ and ${ }^{125} \mathrm{I}$-oGH to fetal skin fibroblasts in culture. Confluent monolayers of fetal fibroblasts plated in 35$\mathrm{mm}^{2}$ wells were washed three times with $2 \mathrm{~mL}$ cold binding buffer and then incubated for 20 to $24 \mathrm{~h}$ at $4^{\circ} \mathrm{C}$ with binding buffer containing ${ }^{125} \mathrm{I}-\mathrm{oPL},{ }^{125} \mathrm{I}-\mathrm{oGH}$, or ${ }^{125} \mathrm{I}$-oPRL $\left(\simeq 1 \times 10^{6}\right.$ $\mathrm{cpm} /$ well) in the absence or presence of unlabeled oPL (200 ng/ $\mathrm{mL})$, oGH $(3 \mu \mathrm{g} / \mathrm{mL})$, or oPRL $(3 \mu \mathrm{g} / \mathrm{mL})$. At the end of the incubation, cells were washed three times with $2 \mathrm{~mL}$ cold binding buffer without BSA and were then incubated for $20 \mathrm{~min}$ at $4^{\circ} \mathrm{C}$ in $1 \mathrm{~mL}$ of $25 \mathrm{mM} N$-2-hydroxyethylpiperazine- $N^{\prime}$-2-ethanesulfonic acid, $10 \mathrm{mM} \mathrm{MgCl}_{2}$ (pH 7.5), containing $0.5 \mathrm{mM}$ DSS or $0.5 \mathrm{mM} \mathrm{BS}^{3}$ at $4^{\circ} \mathrm{C}$. The cells were then washed extensively in cold binding buffer without BSA and solubilized in $50 \mu \mathrm{L}$ of electrophoresis sample buffer (100 mM Tris, pH 6.8, 4\% SDS, 
$0.2 \%$ bromphenol blue, $20 \%$ glycerol, $5 \% \beta$-mercaptoethanol) (22) overnight at $37^{\circ} \mathrm{C}$ in a humidified chamber on a rocking platform. The individual samples were then boiled for $3 \mathrm{~min}$ and analyzed on 7.5\% SDS-polyacrylamide gels (Bio-Rad Laboratories, Richmond, CA) at $12 \mathrm{~mA} /$ gel. The gels were dried using a vacuum drying apparatus (Bio-Rad) and subjected to autoradiography using Kodak X-OMAT film and intensifying screens for 4 to $7 \mathrm{~d}$ at $-70^{\circ} \mathrm{C}$. The molecular weights of the radioactive hormone-receptor complexes were estimated by comparison with prestained molecular weight standards (Sigma Chemical Co., St. Louis, MO).

Data analysis. The binding of ${ }^{125} \mathrm{I}-\mathrm{oPL}$ to fetal sheep skin fibroblasts was examined in the presence or absence of varying concentrations $(0.1 \mathrm{ng}$ to $5 \mu \mathrm{g} / \mathrm{mL})$ of unlabeled oPL, oGH, and oPRL. The total binding of ${ }^{125} \mathrm{I}$-oPL was expressed as the percentage of radiolabeled hormone bound to cell monolayers. Specific binding was calculated by subtracting the amount of binding that occurred in the presence of excess $(10 \mu \mathrm{g} / \mathrm{mL})$ unlabeled hormone (nonspecific binding) from the total binding. The relative potencies of $\mathrm{OPL}, \mathrm{oGH}$, and $\mathrm{OPRL}$ in competing for binding to these sites were estimated by analysis of competitive binding data using LIGAND (23) and INPLOT (GraphPAD Software, San Diego, CA) software. In all experiments, the binding of ${ }^{125} \mathrm{I}$-oPL, ${ }^{125} \mathrm{I}-\mathrm{oGH},{ }^{125} \mathrm{I}$-oPRL to fetal sheep fibroblasts was determined in either duplicate or triplicate samples and was expressed relative to the protein content of each sample (24).

\section{RESULTS}

Time and temperature dependence of ${ }^{125} \mathrm{I}-o P L$ binding to fetal sheep fibroblasts. The binding of ${ }^{125} \mathrm{I}$-oPL to fetal sheep fibroblasts was time and temperature dependent (Fig. 1). At $37^{\circ} \mathrm{C}$, radiolabeled oPL binding was rapid, reaching maximum levels in $30 \mathrm{~min}$ to $1 \mathrm{~h}$ and then declining precipitously to baseline by $2 \mathrm{~h}$ of incubation. The highest specific binding of ${ }^{125} \mathrm{I}-\mathrm{oPL}$ was observed during a 24-h incubation at $4^{\circ} \mathrm{C}$. Under these conditions, there was no apparent degradation of ligand as assessed by rebinding of the tracer to fetal sheep fibroblasts or by trichloracetic acid precipitability. All subsequent experiments were performed at $20-24 \mathrm{~h}$ at $4^{\circ} \mathrm{C}$.

Saturation of oPL binding site in fetal sheep fibroblasts. oPL binding to fetal sheep fibroblasts was saturable during a 24-h incubation at $4^{\circ} \mathrm{C}$ (Fig. 2).

Comparative binding of $o P L, o G H$, and $o P R L$ to fetal sheep fibroblasts. To examine the relative potencies of oPL, oGH, and oPRL in competing for the oPL binding site, fetal sheep fibroblasts were incubated with ${ }^{125} \mathrm{I}-\mathrm{oPL}(\simeq 100000 \mathrm{cpm} /$ well $)$ in the presence or absence of increasing amounts of unlabeled oPL, oGH, or oPRL (Fig. 3). Unlabeled oPL inhibited the binding of ${ }^{125} \mathrm{I}$-oPL in a dose-dependent fashion, with half-maximal inhibition achieved at a concentration of $0.20 \mathrm{nM}$ oPL. Although oGH also was able to displace ${ }^{125} \mathrm{I}$-oPL from fibroblast binding sites, the potency of $\mathrm{OGH}\left(\mathrm{EC}_{50} 1.6-2.4 \mathrm{nM}\right)$ was only one eighth to one twelfth that of oPL. Similarly, oPRL inhibited ${ }^{125} \mathrm{I}$-oPL binding only at high concentrations $\left(\mathrm{EC}_{50}>200 \mathrm{nM}\right)$. In addition, the specific binding of ${ }^{125} \mathrm{I}-\mathrm{oGH}(0.6 \%$ per $250 \mu \mathrm{g}$ protein $)$ and ${ }^{125} \mathrm{I}$-oPRL $(0.04 \%$ per $250 \mu \mathrm{g}$ protein) to fetal sheep fibroblasts was only $1 / 15$ and $1 / 230$ that of ${ }^{125}$ I-oPL $(9.1 \%$ per $250 \mu \mathrm{g}$ protein) (Fig. 4). These findings indicate that fetal sheep fibroblasts bind oPL with high affinity and $\mathrm{OGH}$ and $\mathrm{OPRL}$ with lower affinities.

Cross-linking of ${ }^{125} \mathrm{I}$-oPL and ${ }^{125} \mathrm{I}$-oGH fetal sheep fibroblasts. To characterize further the oPL and oGH binding sites on fetal sheep fibroblasts, cells were incubated with either ${ }^{125} \mathrm{I}-\mathrm{oPL}$ or ${ }^{125} \mathrm{I}-\mathrm{oGH}\left(\right.$ each $\left.\simeq 1 \times 10^{6} \mathrm{cpm}, \simeq 1.0 \mathrm{nM}\right)$ for 20 to $24 \mathrm{~h}$ at $4^{\circ} \mathrm{C}$. Nonspecific wells contained an excess of either unlabeled oPL, $\mathrm{oGH}$, or oPRL (Fig. 5). After washing the cells to remove unbound radioligand, radiolabeled hormones were cross-linked to cellular binding sites using either the membrane-permeable cross-linking reagent DSS or the membrane-impermeable crosslinking reagent $\mathrm{BS}^{3}$. Cross-linking of ${ }^{125} \mathrm{I}-\mathrm{oPL}(22 \mathrm{kD})$ to its binding site produced specific radiolabeled complexes of 130 , 85 , and $60 \mathrm{kD}$ (lane 1). The $130-\mathrm{kD}$ complex was abolished entirely in the presence of $200 \mathrm{ng} / \mathrm{mL}$ unlabeled oPL (lane 2) or $3 \mu \mathrm{g} / \mathrm{mL}$ oGH (lane 3), whereas oPRL was without effect (lane 4). This finding suggests that the $M_{r}$ of the high affinity oPL binding site in fetal fibroblasts is approximately 108000 . The intensities of the 85 - and $60-\mathrm{kD}$ complexes were reduced $\simeq 50$ $80 \%$ by excess unlabeled oPL or oGH, but not oPRL. Studies using DSS or $\mathrm{BS}^{3}$ produced similar cross-linked complexes, suggesting that the cross-linked proteins are associated with the plasma membrane. Cross-linking of ${ }^{125} \mathrm{I}$-oPL to fetal fibroblasts produced one additional complex noted at the top of the gel $(\geq 180 \mathrm{kD})$. This band may represent a large hormone-receptor complex, aggregated radioligand, and/or aggregated hormonereceptor complexes. No specific cross-linking of ${ }^{125} \mathrm{I}-\mathrm{oGH}$ (lanes 5 and 6 ) or ${ }^{125}$ I-oPRL to fetal sheep fibroblasts was detected.

\section{DISCUSSION}

Although numerous studies have demonstrated that PL exerts direct metabolic and growth-promoting effects in fetal and maternal tissues during pregnancy $(4,6,13-18,25-27)$, the initial events in PL action at the cellular level are unknown. The studies described in this report are the first to characterize the binding of PL to isolated cells in culture, providing new insight into the mechanisms by which the hormone may regulate fetal growth.

oPL bound to fetal sheep fibroblasts specifically and with high affinity $\left(\mathrm{EC}_{50} 0.20 \mathrm{nM}\right)$. The binding of oPL was time and temperature dependent; at $37^{\circ} \mathrm{C}$, binding peaked rapidly and then declined, which suggests ligand internalization and/or degradation. Preliminary studies from our laboratory have demonstrated that the oPL receptor in fetal sheep fibroblasts is internalized rapidly after binding oPL at the cell surface; subsequently, the receptor-ligand complex may be recycled back to the cell surface or degraded (28). The highest specific binding of oPL was noted at $4^{\circ} \mathrm{C}$, a temperature at which ligand-receptor processing is minimized (29).

The concentrations of oPL required for half-maximal binding to fetal sheep fibroblasts $(0.20 \mathrm{nM})$ were comparable to the concentrations of oPL in fetal sheep serum $(25-100 \mathrm{ng} / \mathrm{mL}, 1.1-$ $4.4 \mathrm{nM})(8,30,31)$; therefore, fibroblast binding sites in the sheep fetus would likely be occupied by oPL under physiologic conditions. Two observations suggest that these sites bind oPL in preference to $\mathrm{OGH}$ and oPRL: first, the specific binding of radiolabeled oPL was 15 and 230 times greater than that of radiolabeled oGH and oPRL, respectively; and second, unlabeled oPL was eight to 12 times more potent than unlabeled $\mathrm{oGH}$ and $\simeq 1000$ times more potent than unlabeled oPRL in competing for ${ }^{125} \mathrm{I}-\mathrm{oPL}$ binding. The preferential binding of PL to fetal cells in culture may explain in part the differences in potencies of PL, $\mathrm{GH}$, and PRL in various assays of growth-promoting activity in fetal tissues $(6,25-27)$.

The identity of the oPL binding site in fetal fibroblasts is unclear. Cross-linking of ${ }^{125} \mathrm{I}-\mathrm{oPL}$ to intact fetal sheep fibroblasts yielded hormone-receptor complexes of apparent $M_{r}$ of 130000 , 85000 , and 60000 . The $130-\mathrm{kD}$ radiolabeled complex was abolished by excess unlabeled oPL, which suggests that the high affinity oPL receptor in fetal fibroblasts has an $\mathrm{M}_{\mathrm{r}}$ of $\simeq 108000$. The intensities of the $85-$ and $60-\mathrm{kD}$ complexes were reduced markedly, but not abolished, by excess unlabeled oPL or oGH, which suggests the presence of lower affinity or nonspecific hormone binding sites. The $\mathrm{M}_{\mathrm{r}}$ of the high affinity oPL binding site in fetal sheep fibroblasts $(108000)$ differs from the apparent $\mathrm{M}_{\mathrm{r}}$ of the high affinity oPL receptor in fetal sheep liver membranes and soluble liver extracts $(44000 \pm 2000)(32-34)$. The differences in apparent $M_{r}$ of the oPL binding sites in fetal sheep liver and fetal sheep fibroblasts might be explained in several 
ways: first, oPL receptors in various fetal sheep tissues may be heterogeneous in structure, with $44-$ and $108-\mathrm{kD}$ variants; second, the oPL receptor in fetal sheep liver may be cleaved by proteolysis during the preparation of liver microsomes and detergent extracts, yielding a truncated $44-\mathrm{kD}$ protein that contains the high affinity oPL binding domain; or third, the $108-\mathrm{kD}$ oPL receptor in fetal sheep fibroblasts may represent a complex composed of a binding subunit $(44 \mathrm{kD})$ and a closely associated integral membrane protein (60-64 kD). In this formulation, oPL $(22 \mathrm{kD})$ may cross-link to the binding domain, forming a 60 $65-\mathrm{kD}$ complex, or to the complete membrane receptor, forming a $130-\mathrm{kD}$ complex. Nonspecific binding to the associated membrane protein or subunit may produce the $85-\mathrm{kD}$ complex noted in cross-linking studies.

Because the $M_{r}$ of the oPL binding site in fetal fibroblasts is similar to the $\mathrm{M}_{\mathrm{r}}$ of the $\mathrm{GH}$ receptor in various mammalian tissues $(32,35)$, the fibroblast oPL receptor may be a variant of the oGH receptor. Alternatively, the oGH receptor in fetal skin fibroblasts may bind oPL with higher affinity than it binds oGH. The preferential binding of oPL by isolated fetal sheep fibroblasts provides a cellular mechanism by which PL may exert growthpromoting effects in the ovine fetus.

\section{REFERENCES}

1. Tanner JM 1978 Fetus into Man: Physical Growth from Conception to Maturity, 2nd Ed. Harvard University Press, Cambridge, MA, pp 37-51

2. Chard T 1989 Hormonal control of growth in the human fetus. J Endocrinol 123:3-9

3. Gluckman PD 1986 The role of pituitary hormones, growth factors and insulin in the regulation of fetal growth. Ox Rev Repr 8:1-60

4. Ogren L, Talamantes F 1989 Prolactins of pregnancy and their cellular source. Intern Rev Cytology 112:1-65

5. Chan JSD, Robertson HA, Friesen HG 1978 Distribution of binding sites for ovine placental lactogen in the sheep. Endocrinology 102:632-640

6. Freemark M, Handwerger S 1986 The glycogenic effects of placental lactogen and growth hormone in ovine fetal liver are mediated through binding to specific fetal OPL receptors. Endocrinology 118:613-618

7. Freemark M, Comer M, Handwerger S 1986 Placental lactogen and growth hormone receptors in sheep liver: striking differences in ontogeny and function. Am J Physiol 251:E328-E333

8. Freemark M, Comer M, Mularoni T, D'Ercole AJ, Grandis A, Kodack L 1989 Nutritional regulation of the placental lactogen receptor in fetal liver: implications for fetal metabolism and growth. Endocrinology 125:1504-1512

9. Warren WC, Liang R, Krivi GG, Siegel NR, Anthony RV 1990 Purification and structural characterization of ovine placental lactogen. J Endocrinol 126:141-149

10. Hill DJ, Freemark M, Strain AJ, Handwerger S, Milner RDG 1988 Placental lactogen and growth hormone receptors in human fetal tissues: relationship to fetal plasma human placental lactogen concentrations and fetal growth. $\mathbf{J}$ Clin Endocrinol Metab 66:1283-1290

11. Galosy SS, Gertler A, Elberg G, Laird DM 1991 Distinct placental lactogen and prolactin (lactogen) receptors in bovine endometrium. Mol Cell Endocrinol 78:229-236

12. Kessler MA, Duello TM, Schuler LA 1991 Expression of prolactin-related hormones in the early bovine conceptus, and potential for paracrine effect on the endometrium. Endocrinology 129:1885-1895

13. Freemark M, Handwerger $S 1984$ Ovine placental lactogen stimulates glycogen synthesis in fetal rat hepatocytes. Am J Physiol 246:E21-E24

14. Freemark M, Handwerger S 1985 Ovine placental lactogen inhibits glucagoninduced glycogenolysis in fetal rat hepatocytes. Endocrinology 116:12751280

15. Freemark M, Handwerger S 1984 Synergistic effects of ovine placental lactogen and insulin on glycogen metabolism in fetal rat hepatocytes. Am J Physiol 247:E714-E718

16. Hill DJ, Crace CJ, Strain AJ, Milner RDG 1986 Regulation of amino acid uptake and deoxyribonucleic acid synthesis in isolated human fetal fibroblasts and myoblasts: Effect of human placental lactogen, somatomedin-C, multiplication-stimulating activity, and insulin. J Clin Endocrinol Metab 62:753-760

17. Hill DJ, Crace CJ, Milner RDG 1985 Incorporation of $\left[{ }^{3} \mathrm{H}\right]$-thymidine by isolated fetal myoblasts and fibroblasts in response to human placental lactogen (hPL): possible mediation of hPL action by release of immunoreactive SM-C. J Cell Physiol 125:337-344

18. Swenne I, Hill DJ, Strain AJ, Milner RDG 1987 Effects of human placental lactogen and growth hormone on the production of insulin and somatomedin-C/insulin-like growth factor I by human fetal pancreas in tissue culture. J Endocrinol 113:297-303

19. Lassare C, Hardouin S, Daffos F, Forestier F, Frankenne F, Binoux M 1991 Serum insulin-like growth factors and insulin-like growth factor binding proteins in the human fetus. Relationships with growth in normal subjects and in subjects with intrauterine growth retardation. Pediatr Res 29: 219-225

20. Hurley TW, Handwerger S, Fellows RE 1977 Isolation and structural characterization of ovine placental lactogen. Biochemistry 16:5598-5603

21. Colosi P, Thordarson G, Hellmiss R, Singh K, Forsyth IA, Gluckman P, Wood WI 1989 Cloning and expression of ovine placental lactogen. Mol Endocrinol 3:1462-1469

22. Laemmli UK 1970 Cleavage of structural proteins during the assembly of the head bacteriophage T. Nature 227:680-685

23. Munson PJ, Rodbard D 1980 LIGAND: a versatile computerized approach for the characterization of ligand binding systems. Anal Biochem 107: 220-239

24. Bradford MM 1976 A rapid and sensitive method for the quantitation of microgram quantities of protein utilizing the principle of protein-dye binding. Anal Biochem 72:248-254

25. Hurley TW, Thadani P, Kuhn CM, Schanberg SM, Handwerger S 1980 Differential effects of placental lactogen, growth hormone and prolactin on rat liver ornithine decarboxylase activity in the perinatal period. Life Sci $27: 2269-2276$

26. Adams SO, Nissley SP, Handwerger S, Rechler MM 1983 Developmental patterns of insulin-like growth factor I and II synthesis and regulation in rat fibroblasts. Nature 302:150-153

27. Freemark M, Handwerger S 1983 Ovine placental lactogen, but not growth hormone, stimulates amino acid transport in fetal rat diaphragm. Endocrinology 112:402-404

28. Fowlkes J, Freemark M 1991 Placental lactogen binding sites in isolated fetal fibroblasts: characterization, processing and regulation. 73rd Annual Meeting of the Endocrine Society, Washington, DC, p 60 (abstr)

29. Owensby DA, Morton PA, Schwartz AL 1989 Quantitative evaluation of receptor-mediated endocytosis. In: Tartakoff AM (ed) Methods in Cell Biology, Vol 32. Academic Press, New York, pp 305-328

30. Taylor MJ, Jenkins G, Robinson JS, Thorburn GD, Friesen H, Chan JSD 1980 Concentrations of placental lactogen in chronically catheterized ewes and fetuses in late pregnancy. J Endocrinol 85:27-34

31. Chan JSD, Robertson HA, Friesen HG 1978 Maternal and fetal concentrations of ovine placental lactogen measured by radioimmunoassay. Endocrinology 102:1606-1613

32. Freemark M, Comer M, Korner G, Handwerger S 1987 A unique placental lactogen receptor: implications for fetal growth. Endocrinology 120: $1865-1872$

33. Freemark M, Comer M 1988 Differential solubilization of placental lactogen and growth hormone binding sites in sheep liver: further evidence for a distinct placental lactogen receptor in fetal and maternal liver. Endocrinology 122:2771-2779

34. Freemark M, Comer M 1989 Purification of a distinct placental lactogen receptor, a new member of the growth hormone/prolactin receptor family. J Clin Invest 83:883-889

35. Kelly PA, Djiane J, Postel-Vinay M-C, Edery M 1991 The prolactin/growth hormone receptor family. Endocr Rev 12:235-251 